\title{
Clause Combining in Research Articles in Spanish and English: A Systemic-Functional Analysis
}

\author{
Daniel Rodríguez-Vergara \\ National Autonomous University of Mexico, Mexico City, Mexico
}

\begin{abstract}
In this paper we report an analysis of clause connections in two corpora: introductions and conclusions from research articles taken from applied linguistics journals in Spanish and in English. For the analysis, we use the systemic-functional classification of logico-semantic clause nexuses into paratactic and hypotactic expansion (elaboration, extension, and enhancement) and projection (idea and locution). We quantify the frequency with which each nexus type appears in each corpus in order to see if there are significant similarities and differences. The results show that the first two most frequent relations are the same in both corpora but the third is different. We claim that the frequency with which each nexus type appears has functional motivations that are useful for the writers of research articles. The results might have important implications for the writing of research articles in both L1 (first language) and L2 (second language).
\end{abstract}

Keywords: clause combining, research articles, systemic-functional linguistics

\section{Introduction}

Research articles have a prominent value in the transmission of specialized knowledge (Hyland, 2009; Swales, 1990, 2004). They are the medium through which scholars are able to become part of an academic speech community. In addition, as pointed out by Swales (2004), the role of English as a lingua franca generates pressure to write research articles in that language in order to have greatest impact. In the following excerpt, Hyland emphasizes the importance of publishing research articles in English, among other research genres: "universities around the world now require staff to present at international conferences and, more crucially, publish in major, high-impact, peer-reviewed Anglophone journals as a prerequisite for tenure, promotion and career advancement" (Hyland, 2009, p. 67).

Swales (1990) as well points out that there is a growing tendency towards measurement and quantification of research products for funding purposes. As a result, unless research processes become "textual products", it is unlikely that such research will make a contribution to the academic community. Therefore, it is important to detect the factors that determine the "successfulness" of research articles in terms of textual quality. In this respect, there have been studies that report a low linguistic quality in non-native writers of English that aim at publishing research articles in Anglophone journals (Flowerdew, 1999; Gosden, 1992; Li, 2006; St. John, 1987).

Daniel Rodríguez-Vergara, Professor of English, Ph.D., Applied Linguistics Department, National Autonomous University of Mexico. 
In a survey to English-speaking editors of scientific journals (Gosden, 1992), they mentioned that non-native writers of English ran the risk of concealing the high quality of their research under the low quality of their composition. Moreover, when they were asked to indicate the most important factors that had an influence on the acceptance of non-native authors' articles, they mentioned in the first place the clear and logic connection between sentences. (The other factors were the coherent thematic development of sentences, the grammaticality of sentences, and the ability to make claims.)

While the factor of sentence connections demands the attention of applied linguists and ESL (English as a Second Language)/EFL (English as a Foreign Language) professors, it is also necessary to determine the parts of the article where such factor is most likely to play a role in the persuasion of readers. Research articles can be considered a macro-genre (Martin, 1994) whose different sections reflect different discourse patterns (Hood, 2010, 2012) and possess different lexico-grammatical characteristics. Fryer (2012) states that whereas introductions and discussions have a discursive and interpretative nature, methods and results sections contain a more recounting and reporting style. Furthermore, Rosenwasser and Stephen (2009) call introductions and conclusions "two perennial trouble-spots in all kinds of writing" (p. 349). From the perspective of those authors, introductions and conclusions are the most social parts of texts in that they have the function of bringing readers to the textual world and taking them back to the material one. Hence, those sections have been described as "rhetorically the most relevant parts of scholarly texts" (Gruber \& Huemer, 2008, p. 343).

Whereas there have been numerous studies on research article introductions, especially by Swales (1981, 1984, 1990, 2004), conclusion sections have not received much attention (Dudley-Evans, 1994; Holmes, 1997; Peacock, 2002). This is unfortunate if we take into consideration Dudley-Evans' claim (1994) that "it is the section that students claim to have the greatest difficulty with" (p. 20) in articles and theses. For that reason, it is important to carry out a study that explores sentence and clause connections in both, introductions and conclusions.

In this paper we report a systemic-functional analysis of clause connections in introductions and conclusions from research articles in Spanish and English taken from applied linguistics journals. The structure of the paper is as follows. First, we shall present the theoretical background, where we sketch the systemic-functional theory of language and describe how clause complexing is to be understood within that theory. Then, we present the methodological procedures of the study, including the data collection and analysis. Finally, we present the results, discussion, and conclusion.

\section{Theoretical Background}

\section{Systemic Functional Linguistics (SFL)}

Systemic Functional Linguistics (Halliday, 1985, 1994) is a social theory that emphasizes the communicative function of language and whose main interest is to explain the relationship between text and context. In trying to explain this relationship, SFL postulates three contextual variables, viz. field, tenor, and mode of discourse. According to Halliday and Matthiessen, field refers to "the nature of the social and semiotic activity and to the domain of experience this activity relates to". Tenor refers to "the roles played by those taking part in the socio-semiotic activity and to the values that the interactants imbue the domain with". And mode refers to the role "being played by language and other semiotic systems in the situation" (Halliday \& Matthiessen, 2014, p. 33). 
In the text-context hook-up hypothesis (Hasan, 1995), the contextual variables correlate with three metafunctions, viz. ideational, interpersonal, and textual. The ideational metafunction splits into two components, experiential and logical, and resonates with field of discourse. At the level of lexico-grammar, the experiential component includes the system of "transitivity", and generates configurative structures; on the other hand, the logical component includes the system of "clause complexing", and generates iterative structures. In turn, the interpersonal metafunction resonates with tenor of discourse; it includes the systems of "mood", "modality", and "appraisal", and generates prosodic structures in the lexico-grammar. Finally, the textual metafunction resonates with mode of discourse; it includes the systems of "theme" and "focus", and generates periodic structures. For the present study, we will focus on the logical component of the ideational metafunction.

\section{Clause Complexing and the Logical Component}

In order to understand the way clause combining is conceived from the systemic-functional point of view, it is important to consider the difference put forward by Halliday (1989) between clause embedding and clause complexing. On the one hand, embedded clauses are rank-shifted clauses in that they function in the structure of a matrix clause or of a word group. Examples of embedded clauses that function in the structure of a matrix clause are the following:

(1) [[Learning a word $]]$ requires the recognition of a word's auditory sound patterns, orthography, syntactic properties... (Crossley, Salsbury, \& McNamara, 2010, p. 56)

(2) ...we frame [[what we consider a more formally complex learning task for classroom L2 learners.]] (Rothman \& Guijarro-Fuentes, 2010, p. 301)

As can be observed, the systemic-functional convention to mark embedded clauses is with double brackets. In (1), the embedded clause functions as the Subject of the verb "requires"; in (2), it functions as the Complement of the verb "frame". Now, with regards to embedded clauses that function in the structure of a word group, consider the following:

(3) ...pedagogical implications [[deriving from these findings]] call for the design and selection of communication tasks... (Sauro \& Smith, 2010, p. 573)

(4) ...they were unable [[to resolve a problem for themselves...]] (Ohta \& Nakaone, 2004, p. 218)

In (3), the embedded clause functions as the Qualifier of the noun "pedagogical implications"; in (4), it functions as the Qualifier of the adjective "unable". As opposed to subject and complement clauses, which are direct constituents of a clause themselves, qualifying clauses modify clause constituents.

On the other hand, clause complexing has to do with the combination of ranking clauses, not embedded ones. According to Halliday (1994), ranking clause nexuses can be of two types, viz. paratactic and hypotactic. In a paratactic nexus, the clauses have the same status, i.e., one clause simply follows the other, without modifying it. However, in a hypotactic nexus, one clause depends on the other, and therefore, the clauses have a different status. It is important to note here that one clause "depending" on another one is different from one clause "contained" in another one; thus, hypotaxis is different from embedding.

Besides taxis type, which is a grammatical criterion, Halliday (1994) classifies clause nexuses according to their logico-semantic type. There are two main types, viz. expansion and projection. Expansion further includes elaboration, extension, and enhancement, whereas projection includes locution and idea. Each of the five 
terminal categories can be construed in either a paratactic or a hypotactic clause nexus (see Table 1).

Table 1

Examples of Logico-Semantic and Tactic Types

\begin{tabular}{|c|c|c|}
\hline & Parataxis & Hypotaxis \\
\hline Elaboration & $\begin{array}{l}\text { The emergentist view of language learning that we } \\
\text { outlined in the introduction emphasizes that linguistic } \\
\text { competence develops through experience } \| \text {-the more } \\
\text { and more varied experiences a learner has with the L2, } \\
\text { the more that person will develop a strong and broad } \\
\text { communicative repertoire (Pomeratz \& Bell, 2007, p. } \\
\text { 575). }\end{array}$ & $\begin{array}{l}\text {...students had already been unsuccessful in solving } \\
\text { the problem raised, I| which is why they resorted to } \\
\text { asking the teacher... (Ohta \& Nakaone, 2004, p. 236). }\end{array}$ \\
\hline Extension & $\begin{array}{l}\text { Words are not simply referents to objects and } \\
\text { phenomena } \| \text { and word learning is not simply learning } \\
\text { its definition... (Crossley et al., 2010, p. 56). }\end{array}$ & $\begin{array}{l}\text { While many existing studies have examined the } \\
\text { assignment of information structure to sentences, } \| \text { a } \\
\text { fewer studies have looked at L2 learners' ability to } \\
\text { identify and process anomalies... (Reichle, 2010, p. } \\
54 \text { ). }\end{array}$ \\
\hline Enhancement & $\begin{array}{l}\text { This resource, because it is limited, provides } \\
\text { constraints on the ability to implement these activities } \\
\text { concurrently, I| and therefore, particularly sets limits } \\
\text { on divided attention between tasks... (Wickens, 2007, } \\
\text { p. 178). }\end{array}$ & $\begin{array}{l}\text { As new words emerge, II L2 learners also create } \\
\text { networks of links between the new words and already } \\
\text { learned words... (Crossley et al., 2010, p. 56). }\end{array}$ \\
\hline Locution & $\begin{array}{l}\text {...one was warned before he crossed the U.S. border: II } \\
\text { "You better not speak like that (i.e., in Maya) up there } \\
\text { or they'll know you're not from there" (Whiteside, } \\
\text { 2008, p. 105). }\end{array}$ & $\begin{array}{l}\text { [Author] points out } \| \text { that there are several limitations } \\
\text { in communicative language teaching... (Goldoni, 2008, } \\
\text { p. } 65) \text {. }\end{array}$ \\
\hline Idea & $\begin{array}{l}\text {...we would have to wonder, } \| \text { what is it that "black" } \\
\text { literature renders? (Mungia, 2010, p. 3). }\end{array}$ & $\begin{array}{l}\text { Basically, I think \|| that IL performance is learning } \\
\text { transfer... (James, 2007, p. 95). }\end{array}$ \\
\hline
\end{tabular}

First, in elaboration nexuses, one clause elaborates on the meaning of another by restating, exemplifying, or clarifying it; each of those elaboration subtypes is equivalent to the meanings of Latin locutions e.g., i.e., and viz., respectively (Matthiessen, 1995). Second, in extension nexuses, one clause extends the meaning of another through addition (and), variation (but), and alternative (or). Third, in enhancement nexuses, one clause enhances the meaning of another in terms of time, space, manner, cause, and condition. Fourth, in locution nexuses, one clause is projected by another that contains a verbal process such as say, tell, ask, etc.. Finally, in idea nexuses, one clause is projected by another that contains a mental process such as think, believe, consider, etc..

It has been reported that the frequency with which the variables of logico-semantic and taxis types combine depends on the particular register in which they are expressed (Matthiessen, 2002; Nesbitt \& Plum, 1988; Sellami Baklouti, 2011). Thus, in the study presented in this paper, we explored in our corpora the frequencies with which each of the clause nexus types appears. For the analysis, we followed the methodology presented below.

\section{Methodological Procedures}

\section{Data Collection}

For the present study, 40 research articles in English and 40 in Spanish were collected. The selection of the articles and journals was motivated by the need to control as much as possible the following variables. First, they had to be in electronic format, so that the analysis could be carried out on a word processor. Second, in order to narrow the domain of experience, they had to be published in refereed journals whose title contained the term "applied linguistics" (or its correlate in Spanish). Third, they had to be no older than 10 years (i.e., from 2002 on, 
since the research started in 2012). Fourth, they had to contain an opening introductory section (not necessarily explicitly titled "Introduction") and a closing one necessarily explicitly titled "Conclusion" (in order to discern its limit from other previous sections). Fifth, the articles in English had to be written by American authors, and the ones in Spanish by Mexican authors, for which purpose we used Wood's (2001, p. 79) "strict" criterion which dictates that authors have to have names native to the country concerned, and work in an institution in that country.

Some of these filters could be set up in an automatic academic database engine search, and some of them had to be checked manually with the results from the automatic search. Because there are more refereed applied linguistic journals in English than in Spanish, the English corpus has articles from four international journals, whereas the Spanish one, from two. The articles deal with several topics from the applied linguistics discipline, many of them being about teaching and learning an L2, and also about discourse analysis, sociolinguistics, language acquisition, pragmatics, corpus linguistics, etc.. In total, we formed an English corpus with 40 introductions (17,770 words) and 40 conclusions (17,768 words), and a Spanish one with 40 introductions (15,050 words) and 40 conclusions (12,986 words).

\section{Data Analysis}

Each of the subtexts (introductions and conclusions) was first divided into clause complexes. Following Halliday (1989), who says that "The clause complex is, in fact, what the sentence (in writing) comes from", the division of the subtexts into clause complexes was made on the basis of sentence limits. After that, each clause complex was divided into ranking clauses. Naturally, some sentences contained only one ranking clause, in which case they are technically not complexes but simplexes. Later, all ranking clause nexuses were classified according to logico-semantic and taxis type. Finally, we quantified the frequency with which the nexus types appeared in each of the two corpora for comparison purposes. We present the results below.

\section{Results and Discussion}

We will start by presenting the results of the Spanish corpus. In total, we found 849 sentences, and of those, 452 (53\%) were clause simplexes and 397 (47\%) were clause complexes. Within those complexes, there were a total of 603 clause nexuses (held between two clauses). Figure 1 presents the percentage of each nexus type.

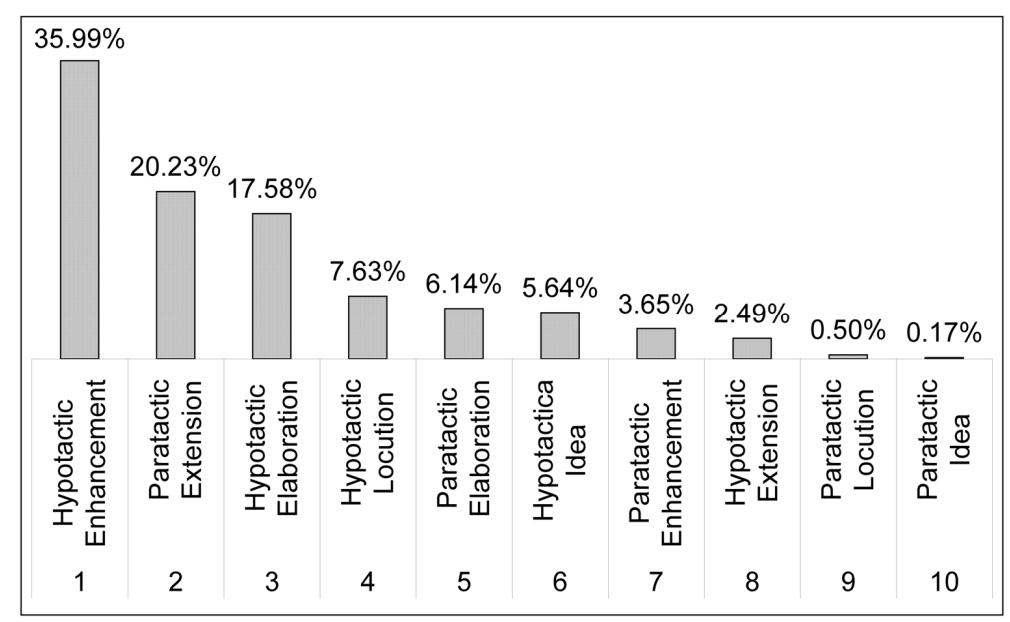

Figure 1. Percentages of nexus types in the Spanish corpus. 
As can be observed, by far, the majority of the nexuses are hypotactic enhancements (35.99\%). In contrast, the paratactic version of enhancement appeared only in $3.65 \%$ of all nexuses. This is in line with the findings by Matthiessen (2002), who also reported hypotactic enhancement as the most frequent nexus type in a registerially diverse corpus containing both written and spoken samples. He also found that the hypotactic version of enhancement is much more frequent than the paratactic version.

The high frequency of hypotactic enhancement relations might be due to the fact that such nexus type is the widest category, since it includes all the adverbial clauses that construe circumstantial meaning in terms of time, space, manner, cause, and condition. As explained by Matthiessen (2007), circumstantial meaning can be construed by means of clause adjuncts, hypotactic clauses, paratactic clauses, and sentences:

(5) Because of children's advancement beyond bilingualism, future measurement issues would have to address proficiencies in their third, fourth, or even more languages.

(6) Since the children are moving beyond bilingualism, future measurement issues would have to address proficiencies in their third, fourth, or even more languages. (Caldas, 2007, p. 309)

(7) The children are moving beyond bilingualism, so future measurement issues would have to address proficiencies in their third, fourth, or even more languages.

(8) The children are moving beyond bilingualism. Therefore, future measurement issues would have to address proficiencies in their third, fourth, or even more languages.

All these examples construe circumstantial meaning in terms of cause. However, (5) construes it by means of an adjunct, (6) with a hypotactic clause, (7) with a paratactic clause, and (8) with a sentence. Examples (5) to (8) form a scale that goes from tighter to looser integration of the circumstantial element. Regarding this scale, Matthiessen (2007) reported that, in his varied corpus, tighter elements had higher frequencies than looser ones. This is likely the reason why we obtained a highest percentage of hypotactic enhancements than paratactic.

In Spanish, hypotactic enhancement tends to be construed with both simple and complex conjunction and preposition groups:

(9) Simple conjunction group: ...si el usuario introdujo 'desplome' y 'objeto' como palabras clave del término buscado, la técnica indicaría que no se localizó ningún término. (Castillo \& Sierra, 2003, p. 70)

[....if the user introduced 'collapse' and 'object' as keywords of the term searched, the technique would indicate that no term was found.]

(10) Complex conjunction group: Una vez que han sido analizados los datos, podemos afirmar que esta propuesta sí contribuye a que los alumnos desarrollen mayor apertura, respeto y curiosidad hacia la alteridad. (Mallén, 2003, p. 134)

[Once the data have been analyzed, we can assert that this proposal does help students to develop greater openness, respect and curiosity towards otherness.]

(11) Simple preposition group: ...para evaluar este procedimiento, se comparan los resultados con la información proporcionada por el especialista. (Medina \& Buenrostro, 2003, p. 16)

[...to evaluate this procedure, the results are compared with the information provided by the specialist.]

(12) Complex preposition group: ...es necesario realizar pruebas exhaustivas con el fin de dar mayor sustento al empleo de lo que aqui se ha propuesto para determinar relaciones léxicas. (González \& Jimémez, 2003, p. 87)

[...it is necessary to carry out exhaustive tests in order to give further support to the use of what has here been proposed for determining lexical relations.]

Contrary to its English correlate, the Spanish complex conjunction group in (10) uses the dependence conjunction que (that). On the other hand, the complex preposition group in (12) translates literally as "with the 
purpose of"; hence, this can be regarded as a more lexical than grammatical logico-semantic marker, at least when compared to other purpose markers such as para (in order/so that/to).

Figure 1 also shows that the second most frequent nexus type is paratactic extension (20.23\%). As opposed to enhancement, extension highly favors parataxis. In contrast, the hypotactic version of extension appeared only in $2.49 \%$ of all nexuses. This fact is also in line with Matthiessen's (2002) statistics, where extension is overwhelmingly paratactic. Whereas in hypotactic enhancement we observe that dependent clauses normally contain binders such as como (since), porque (because), cuando (when), etc., the combination of parataxis and extension generates coordinated clauses with linkers such as $y$ (and), o (or), pero (but), etc.:

(13) ...es un método heurístico y, en esencia, se basa en analogías. (Castillo \& Sierra, 2003, p. 70)

[...it is a heuristic model and, in essence, is based in analogies.]

(14) ...se puede consultar a especialistas del área, directamente, o bien pueden consultarse textos correspondientes al dominio que se estudia. (Alarcón \& Sierra, 2003, p. 130)

[...you can directly consult specialists in the area, or instead you can consult texts that correspond to the studied domain.]

(15) En este escenario, tienen la posibilidad de mejorar sus habilidades orales pero, típicamente, no tienen la oportunidad de practicar habilidades académicas... (Spicer-Escalante, 2007, p. 66)

[In this situation, they have the possibility to improve their oral skills but, typically, they do not have the opportunity to practice academic skills...]

Although we commonly observe the use of coordinating conjunctions in extension nexuses, they can also appear in paratactic enhancements. For instance, the conjunction $y$ (and) in (13) simply adjoins two clauses, but when it expresses a sense of succession (and then) or result (and so), it is considered paratactic enhancement. One interesting characteristic of extension conjunctions is that they frequently appear together with an adjunct, as in (13) to (15): y, en escencia (and, in essence); o bien (or instead); pero, típicamente (but, typically).

We will finally comment on the third most frequent nexus type in Figure 1, viz. hypotactic elaboration. The figure shows a significant difference between the hypotactic version of elaboration (17.58\%) and the paratactic one (6.14\%), although not as considerable as in enhancement and extension. In this case, our statistics differ from Mathhiessen's, since in his registerially diverse corpus, he found that elaboration appeared almost equally in both taxis types. Thus, hypotactic elaboration might be especially significant in our Spanish research articles.

The combination of elaboration with hypotaxis generates non-defining relative clauses as well as present and past participle clauses:

(16) Non-defining relative clause: ...algunos afijos de tipo derivativo también fueron identificados automáticamente (los direccionales), lo que indica su importancia relativa en el chuj. (Medina \& Buenrostro, 2003, p. 30)

[...some derivational affixes were also identified automatically (the directional ones), which indicates its relative importance in Chuj.]

(17) Present participle clause: ....se utilizan como categorías básicas en el nivel del texto las de "enunciador" y "destinatario", entendiendo por tales a aquellas entidades-con referentes identificados o no-a las que se les atribuye o destina, respectivamente, una enunciación... (Pérez, 2005, p. 59)

[The basic categories "sayer" and "receiver" are used at the text level, being understood as the entities-with identified referents or not— to which an enunciation is attributed or aimed at, respectively...]

(18) Past participle clause: En este trabajo enfrentamos el problema de contención de un conjunto en otro, derivado de la noción de subsunción... (González \& Jiménez, 2003, p. 82)

[In this paper we will face the problem of one group being included inside another, derived from the notion of nesting...] 
Whereas non-defining relative clauses such as the one in (16) are ranking clauses, defining relative clauses are non-ranking or embedded ones (Halliday, 1989). Moreover, the present and past participle clauses in (17-18) might as well be replaced by finite non-defining relative ones (The basic categories "sayer" and "receiver" are used at the text level, which is understood as the entities...; In this paper we will face the problem of one group being included inside another, which derives from...).

Relative clauses are expressions that incorporate into a matrix clause to modify one of its elements or its entirety. They are able to do this because they are of a nominalized nature (Shibatani, 2009). Nominalization makes clauses syntactically more condensed, which is a feature that has been called "complex condensation" by Mathesius (1975). Research article writers are particularly fond to condensation strategies because with them they can say more things with fewer words. For that reason, the frequent use of hypotactic elaboration appears to be significant in this corpus.

After having presented the results in the Spanish corpus, we shall now present those corresponding to the English one. In total, we found 1,272 sentences, and of those, 627 (49\%) were clause simplexes and 645 (51\%) were clause complexes. Within those complexes, there were a total of 1,010 clause nexuses. Figure 2 presents the percentages of each nexus type.

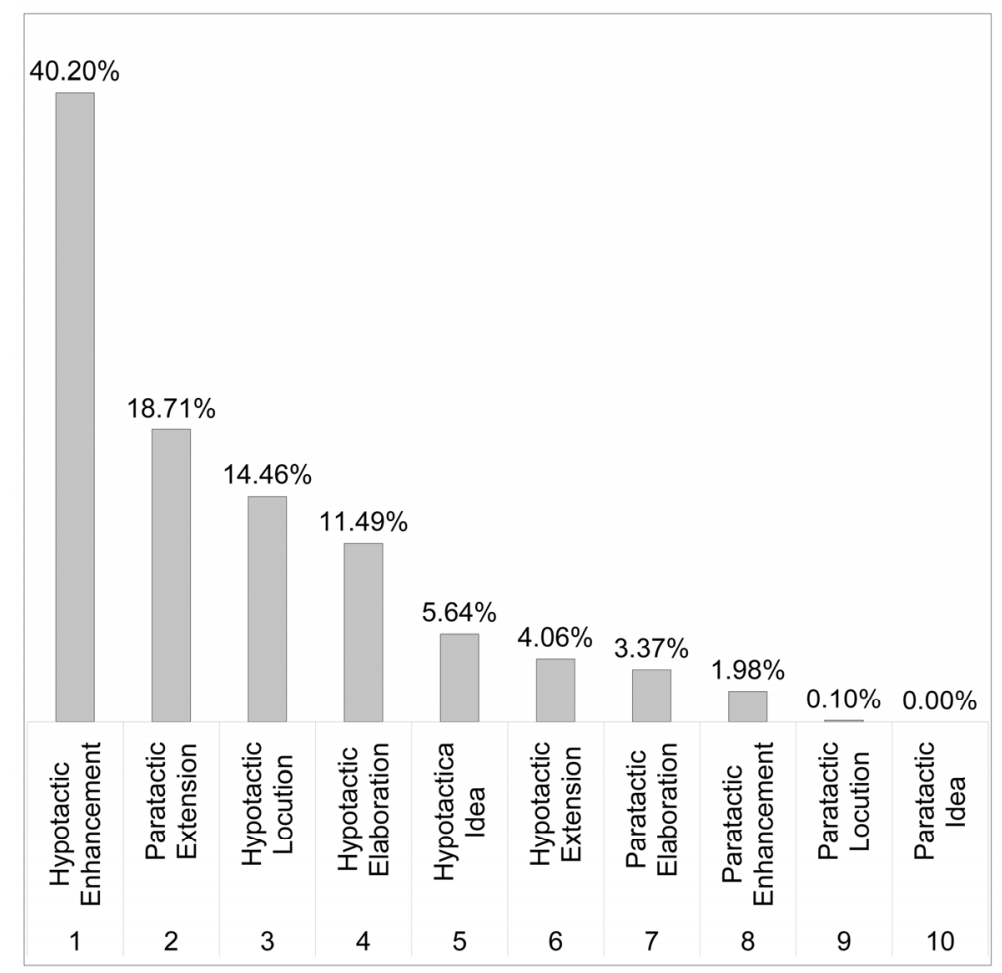

Figure 2. Percentages of nexus types in the English corpus.

Again, we will comment on the three most frequent relation types. Firstly, we see in this figure that, as in the Spanish corpus, the most frequent relation type is by far hypotactic enhancement (40.20\%). In contrast, paratactic enhancement is in the eighth position (1.98\%). Secondly, paratactic extension is the second most frequent relation type (18.71\%), also coinciding with the Spanish corpus. On the other hand, the hypotactic version of extension is in the sixth position (4.06\%). Finally, hypotactic locution is the third most frequent relation type 
(14.46\%), a result that differs from the Spanish corpus, where we see that hypotactic elaboration is more frequent than hypotactic locution. As opposed to the high frequency of the hypotactic version, the paratactic version of locution is in the penultimate position, with only .10\%. This result is in contrast with Mathiessen's (2002) study, where he found that paratactic locution was as frequent as its hypotactic counterpart. Thus, it seems that hypotactic locution is especially significant in the English corpus.

The combination of locution with hypotaxis yields reported speech constructions, whereas paratactic locution construes direct speech. In a research writing context, this means that writers use hypotactic locution to, among other things, cite other authors by paraphrasing, and paratactic locution to cite them verbatim:

(19) Hypotactic locution: [Author] has suggested that, in the case of obligatory target language rules, learners move from invariant non-application of target language rules to variable application, to invariant application. (Bayley \& Langman, 2004, p. 316)

(20) Paratactic locution: This belief is asserted by [Author], who says that "the use of low-rise on yes/no interrogatives may indeed sound 'patronising', or 'ingratiating' to Americans, who are more likely to use high-rise..." (Levis, 2002, p. 57)

Whereas in extension, clause nexuses are typically marked by conjunction and preposition words and phrases, in projection, verbal processes construe the nexuses. In examples (19-20) the verbal processes are in bold. In (19) the process suggested is used to state an author's research result in a subtle fashion. In that sense, this process is one that implies a possibility, not a clear-cut fact. Hyland (1998) terms those lexical elements that avoid making definite statements in academic writing "hedges". In turn, they are also analyzed as a type of expanding heteroglossia within the general system of APPRAISAL (Martin \& White, 2005).

The use of the process suggest in our English corpus is relevant since it was the most frequent one, with 39 tokens. Of those 39 tokens, 16 appear in introductions and 23 in conclusions. Perhaps the use of this process is more common in conclusions because in this part of articles writers explain the significance of the results, as is suggested by Dudley-Evans (1994).

In sum, a significant difference between the Spanish and the English corpus is that the latter makes a more frequent use of hypotactic locution than hypotactic elaboration and vice versa. It seems that the English articles "speak" more than the Spanish one, as it were, which suggests that Mexican authors do not explain, speculate, and comment on their ideas as much as American authors. However, more research needs to be done in order to gather more evidence in favor or against this issue.

In general, both the Spanish and the English corpus show a statistically significant preference for hypotaxis. In fact, of all the nexuses in Spanish, 77\% were hypotactic and 22\% were paratactic, whereas in English, 76\% were hypotactic and 24\% were paratactic. This contrasts sharply with Matthiessen's (2002) statistics, where the division of labor between the two taxis types is roughly equal. Thus, hypotaxis is likely to have an important role in the composition of our research articles, as shown in another study, Sellami Baklouti (2011), where she analyzed 120 research article abstracts from Educational Science, Linguistics, Materials Science, Physical Chemistry, and Sociology. In her results, $68 \%$ of all the nexuses are hypotactic and $32 \%$ are paratactic.

In both, hers and our study, hypotaxis seems to be accomplishing at least three important functions. First, with hypotaxis, it is possible to condense information, as was explained above with relative clauses. It is clear that authors need to condense information in abstracts. However, we claim that an entire research article is usually 
constrained by space limitations (those that are specified in the instructions for authors), including the information contained in the introduction and conclusion. Secondly, with hypotactic clause nexuses, it is possible to manipulate the order of the clauses in an easier way than in paratactic clause complexes. This is because whereas a secondary clause in a hypotactic nexus can precede or follow the primary clause, in a paratactic nexus, secondary clauses always follow primary ones. As stated by Matthiessen and Thompson (1988), the order of clauses is a result of global discourse needs such as marking the limits between textual sections. Finally, as pointed out by Sellami Baklouti (2011), writers prefer hypotaxis because it can be used as a persuasion strategy in the sense that the content of the secondary clause usually presents given information, whose veracity is not subject to negotiation (especially in non-finite clauses).

\section{Conclusion}

In this paper we have presented an analysis of the frequency with which different clause nexus types appear in introductions and conclusions of research articles in Spanish and in English. We have found important differences when comparing the frequencies of the two corpora, and when comparing our data with Matthiessen's (2002), who analyzed a registerially diverse corpus. Significantly, the Spanish texts use more hypotactic elaboration than hypotactic locution, whereas the English texts show the opposite. In addition, elaboration and locution were the two areas where we found divergence between our data and Matthiessen's. While he found that, in both elaboration and locution, the division of labor between parataxis and hypotaxis was roughly 50/50; in our data, the hypotactic versions of those two logico-semantic types were overwhelming.

It has been claimed here that hypotaxis plays an important role in the writing of research articles, which is also supported by Sellami Baklouti's (2011) analysis of abstracts. This study has also shown how the frequencies with which language options are chosen vary depending on the nature of texts (Nesbitt \& Plum, 1988). This supports the text-context hook-up hypothesis (Hasan, 1995), which says that the contextual variables correlate with the metafunctions. In our study, logico-semantic relations are used to construe the field of discourse in applied linguistics research articles, where there is a preference to connect clauses by means of hypotactic enhancement (circumstantial meaning) and paratactic extension (coordination).

We have investigated one aspect of research articles that is likely to have an influence on the acceptance of non-native authors' articles in English, viz. clause connections. We have also shown that there are more similarities than differences in Spanish and English research articles as far as logico-semantic relations are concerned, which might represent an advantage for non-native writers of articles in English since some of the linguistic strategies could be transferred from one language to the other. However, more research needs to be done with the other research article sections that have not been taken into account here (methods and results) and in other fields of study in order to detect other factors that determine the "successfulness" of research article writing.

\section{Corpus References}

Alarcón, R., \& Sierra, G. (2003). El rol de las predicaciones verbales en la extracción automática de conceptos (The role of verbal predications in automatic concept-extraction). Estudios de Lingüistica Aplicada, 38, 129-144.

Bayley, R., \& Langman, J. (2004). Variation in the group and the individual: Evidence from Second Language Acquisition. International Review of Applied Linguistics, 42, 303-318. 
Caldas, S. J. (2007). Changing bilingual self-perceptions from early adolescence to early adulthood: Empirical evidence from a mixed-methods case study. Applied Linguistics, 29, 290-311.

Castillo, G., \& Sierra, G. (2003). Algoritmo flexibilizado y agrupamiento semántico (Flexible algorithm for semantic clustering). Estudios de Lingüística Aplicada, 38, 69-80.

Crossley, S. A., Salsbury, T., \& McNamara, D. S. (2010). The development of semantic relations in second language speakers: A case for Latent Semantic Analysis. Vigo International Journal of Applied Linguistics, 7, 55-74.

Goldoni, F. (2008). Designing a foreign language curriculum in postsecondary education drawing from the multiliteracy, functionalist, and genre-based approaches. Vigo International Journal of Applied Linguistics, 5, 63-86.

González, J. F., \& Jiménez, H. (2003). Determinación de flexiones léxicas con base en el grado subsunción (Determining lexical relations based on subsumption ratio). Estudios de Lingüística Aplicada, 38, 81-87.

James, M. A. (2007). Interlanguage variation and transfer of learning. International Review of Applied Linguistics, 45, 95-118.

Levis, J. M. (2002). Reconsidering low-rising intonation in American English. Applied Linguistics, 23, 56-82.

Mallén, M. T. (2003). La alteridad en las clases de inglés (Otherness in English classes). Estudios de Lingüística Aplicada, 37 , 119-136.

Medina, A., \& Buenrostro, E. C. (2003). Características cuantitativas de la flexión verbal del chuj (Quantitative aspects of verbal inflexion in Chuj). Estudios de Lingüistica Aplicada, 38, 15-31.

Mungía, R. (2010). De la oralidad a la escritura: Un acercamiento al conflicto lingüístico en los pueblos francófonos del África negra (From speaking to writing: An approach to the linguistic conflict of francophone peoples in Black Africa). ReLingüistica Aplicada, 7, 1-10.

Ohta, A. S., \& Nakaone, T. (2004). When students ask questions: Teacher and peer answers in the foreign language classroom. International Review of Applied Linguistics, 42, 217-237.

Pérez, S. I. (2005). La construcción discursiva de los participantes: análisis de una intervención en el Primer Congreso Feminista de Yucatán (1916) (The discursive construction of participants: Analysis of a conference paper from the First Feminist Congress in Yucatán (1916)). Estudios de Lingüistica Aplicada, 42, 57-73.

Pomerantz, A., \& Bell, N. D. (2007). Learning to play, playing to learn: FL learners as multicompetent language users. Applied Linguistics, 28, 556-578.

Reichle, R. V. (2010). Judgments of information structure in L2 French: Nativelike performance and the Critical Period Hypothesis. International Review of Applied Linguistics, 48, 53-85.

Rothman, J., \& Guijarro-Fuentes, P. (2010). Input quality matters: Some comments on input type and age-effects in adult SLA. Applied Linguistics, 31, 301-306.

Sauro, S., \& Smith, B. (2010). Investigating L2 performance in text chat. Applied Linguistics, 31, 554-577.

Spicer-Escalante, M. (2007). Análisis lingüístico de la escritura bilingüe (español-inglés) de los hablantes de español como lengua hereditaria en los Estados Unidos (Linguistic analysis of bilingual writing (Spanish-English) of Spanish Heritage speakers in the United States). Estudios de Lingüistica Aplicada, 45, 63-80.

Whiteside, A. (2008). Research on transnational Yucatec Maya-speakers negotiating multilingual California. Journal of Applied Linguistics, 3, 103-112.

Wickens, C. (2007). Attention to the second language. International Review of Applied Linguistics, 45, 177-191.

\section{References}

Dudley-Evans, T. (1994). Genre analysis: An approach to text analysis for ESP. In M. Coulthard (Ed.), Advances in written text analysis (pp. 219-228). London: Routledge.

Flowerdew, J. (1999). Problems of writing for scholarly publication in English: The case of Hong Kong. Journal of Second Language Writing, 8, 243-64.

Fryer, D. L. (2012). Analysis of the generic discourse features of the English-language medical research paper: A systemic functional approach. Functions of Language, 19, 5-37.

Gosden, H. (1992). Research writing and NNSs: From the editors. Journal of Second Language Writing, 1, 123-139.

Gruber, H., \& Huemer, B. (2008). Two views on text structure: Using rhetorical structure theory and register and genre theory in improving students' academic writing. Odense Working Papers in Language and Communication, 29, 332-365.

Halliday, M. A. K. (1985). An introduction to functional grammar. London: Edward Arnold.

Halliday, M. A. K. (1989). Spoken and written language (2nd ed.). Oxford: Oxford University Press.

Halliday, M. A. K. (1994). An introduction to functional grammar (2nd ed.). London: Edward Arnold. 
Halliday, M. A. K., \& Matthiessen, C. M. I. M. (2014). Halliday's introduction to functional grammar (4th ed.). London: Routledge. Hasan, R. (1995). The conception of context in text. In P. H. Fries \& M. Gregory (Eds.), Discourse in society: Systemic functional perspectives: Meaning and choice in language: Studies for Michael Halliday (pp. 183-296). New Jersey: Ablex.

Holmes, R. (1997). Genre analysis and the social sciences: An investigation of the structure of research article discussion sections in three disciplines. English for Specific Purposes, 16, 321-337.

Hood, S. (2010). Appraising research: Evaluation in academic writing. London: Palgrave Macmillan.

Hood, S. (2012). Voice and stance as appraisal: Persuading and positioning in research writing across intellectual fields. In K. Hyland \& C. Sancho Guinda (Eds.), Stance and voice in written academic genres (pp. 51-68). London: Palgrave Macmillan.

Hyland, K. (1998). Hedging in scientific research articles. Amsterdam: Benjamins.

Hyland, K. (2009). Academic discourse: English in a global context. London: Continuum.

Li, Y. (2006). A doctoral student of physics writing for publication: A sociopolitically oriented case study. English for Specific Purposes, 25, 456-78.

Martin, J. R. (1994). Macro-genres: The ecology of the page. In Z. H. Wang (Ed.), Genre studies: Collected works of J. R. Martin (Vol. 3, pp. 78-126). Shanghai: Shanghai Jiao Tong University Press.

Martin, J. R., \& White, P. R. R. (2005). The language of evaluation: Appraisal in English. New York: Palgrave Macmillan.

Mathesius, V. (1975/1961). A functional analysis of present day English on a general linguistic basis. In J. Vachek, Ed.; L. Dušková, Trans. The Hague: Mouton.

Matthiessen, C. M. I. M. (1995). Lexicogrammatical cartography: English systems. Tokio: International Language Science Studies.

Matthiessen, C. M. I. M. (2002). Combining clauses into clause complexes: A multi-faceted view. In J. Bybee \& M. Noonan (Eds.), Complex sentences in grammar and discourse: Essays in honor of Sandra A. Thompson (pp. 237-322). Amsterdam: Benjamins.

Matthiessen, C. M. I. M. (2007). The architecture of language according to systemic functional theory: Developments since the 1970s. In R. Hasan, C. M. I. M. Matthiessen, \& J. Webster (Eds.), Continuing discourse on language (Vol. 2, pp. 505-561). London: Equinox.

Matthiessen, C. M. I. M., \& Thompson, S. A. (1988). The structure of discourse and "subordination". In J. Haiman \& S. A. Thompson (Eds.), Clause combining in grammar and discourse (pp. 275-329). Amsterdam: Benjamins.

Nesbitt, C., \& Plum, G. (1988). Probabilities in a systemic-functional grammar: The clause complex in English. In R. P. Fawcett \& D. Young (Eds.), New developments in systemic linguistics (Vol. 2, pp. 6-39). London: Pinter.

Peacock, M. (2002). Communicative moves in the discussion section of research articles. System, 30, 479-497.

Rosenwasser, D., \& Stephen, J. (2009). Writing analytically (5th ed.). Boston: Thomson Wadsworth.

Sellami Baklouti, A. (2011). The impact of genre and disciplinary differences on structural choice: Taxis in research article abstracts Text \& Talk, 31, 503-523.

Shibatani, M. (2009). Elements of complex structures, where recursion isn't: The case of relativization. In T. Givón \& M. Shibatani (Eds.), Syntactic complexity: Diachrony, aquisition, neuro-cognition, evolution (pp. 163-198). Amsterdam: Benjamins.

St. John, M. J. (1987). Writing processes of Spanish scientists publishing in English. English for Specific Purposes, 6, 113-20.

Swales, J. M. (1981). Aspects of article introductions. Birmingham: Language Studies Unit, University of Aston.

Swales, J. M. (1984). Research into the structure of introductions to journal articles and its application to the teaching of academic writing. In R. Williams, J. M. Swales, \& J. Kirkman (Eds.), Common grounds: Shared interests in ESP and communication studies (pp. 77-86). New York: Pergamon Press.

Swales, J. M. (1990). Genre analysis: English in academic and research settings. Cambridge: Cambridge University Press.

Swales, J. M. (2004). Research genres: Explorations and applications. Cambridge: Cambridge University Press.

Wood, A. (2001). International scientific English: The language of research scientist around the world. In J. Flowerdew \& M. Peacock (Eds.), Research perspectives on English for academic purposes (pp. 71-83). Cambridge: Cambridge University Press. 